\title{
Communication Power as a Mediator on Networking and Career Success: A Structural Equation Modeling Approach
}

\author{
Saodah Wok ${ }^{1}$ and Junaidah Hashim ${ }^{2}$ \\ ${ }^{1}$ Department of Communication, International Islamic University Malaysia (IIUM), Jalan Gombak, \\ Kuala Lumpur, Malaysia \\ ${ }^{2}$ Department of Business Administration, IIUM, Jalan Gombak, Kuala Lumpur, Malaysia \\ Correspondence should be addressed to: Saodah Wok; wsaodah@iium.edu.my,
}

Received date: 22 September ; Accepted date: 13 February 2017; Published date: 27 February 2017

Academic Editor: Dang Merduwati Hashim

Copyright (C) 2017. Saodah Wok and Junaidah Hashim . Distributed under Creative Commons CC-BY 4.0

\begin{abstract}
This study investigates the mediating effect of communication power on networking and career success. It also tests the moderating effects of proactive personality and self-efficacy in the model. The study employs a quantitative research design. It uses a survey method using questionnaire for data collection.The population of interest is the employees at the supervisory or managerial position in various organizations in Malaysia. A sample size of 400 supervisor/managers was used for the study. Most of the measures were adapted from established scales. The findings reveal that there is a mediating effect of communication power on the relationships. This means that mentoring influences the communication power which in turn influences career success. This study significantly contributes to the existing knowledge because not much is known about communication power effect on career success except Castells work (2007). With the present influence of communication technology at the workplace, the findings of this study are useful to Human Resource (HR) practitioners for strategizing organisation career management and mentoring programme. This study does not only examine the effect of the two variables, information power and career success; it goes a step further by taking mentoring into the model.
\end{abstract}

Keywords: Career success, Communication and information power, Mentoring, Proactive personality.

\section{Introduction}

Information is power. Developing a network of contacts inside and outside of organization provides immense and valuable information which can be beneficial in many ways. Indeed, internal and external contacts can provide opportunities to advance in one's career. Networking behaviors build and maintain informal contacts to enhance career success (Forret \& Dougherty, 2004; Luthans, Rosenkrantz \& Hennessey, 1985; Michael \& Yukl, 1993). Networking is positively related to both objective and subjective measures of

Cite this Article as: Saodah Wok and Junaidah Hashim (2017)," Communication Power as a Mediator on Networking and Career Success: A Structural Equation Modeling Approach ", Communications of the IBIMA, Vol. 2017 (2017), Article ID 424146, DOI: 10.5171/2017.424146 
career success (Forret \& Dougherty, 2004; Langford, 2000; Michael \& Yukl, 1993; Orpen, 1996). Similarly, literature suggests that networking behaviors, such as having business discussion, attending conference, and keep contacting colleagues, enhance career success (Nierenberg, 2002; Torres, 2005; Welch, 1980).

However, people rarely make use of their existing networks effectively. They think that if they can perform well, they can be acknowledged and get promoted. With modern technology, they cannot stay in isolation. Hopefully, the internally connected employees are also popular to the outside organizations. That is why boundary spanners are useful for organization linkages. Therefore, they have to harness the contemporary technology to project themselves because acknowledgement comes across borders, not just organization, but worldwide. If they want support from peers, they can get acknowledged for the expertise through making use of their linkages.

The present study will extend the existing knowledge in this field. Although, we know networking affects career success; not much is known about how it happens. With the empirical evidence on how network affects career success, both individual and organization will get the benefits. Individuals, who progress well in their career, tend to be loyal and organization is able to retain them (Aquino, Griffeth, Allen, \& Hom, 1997).

This study contributes to the communication literature. For example, this study integrates the issues of networking behaviors, communication power, career success and personality. Therefore, this study is unique in such a way that networking behaviors involve both the internal and external entities to the organization. They are studied in relation to information power and relationship power. Such knowledge can help employees and managers to better target their networking behaviors internally and externally. Relatively little, or in some cases no, prior research exists on these outcomes. The present study tests a comprehensive model of employees' career success involving several predictors, which are based on past research. It is expected that such model is able to provide evidence regarding the network contribution to career success among employees.

\section{Theoretical Framework}

\section{Social Capital Theory}

Modern theories of Social Capital (Seibert, Kraimer \& Liden, 2001) focus on the importance of bridging and networking functions as interactions and networking are bound to improve profits such as reinforced identity and recognition (Bourdieu, 1986; Burt, 1992; Coleman, 1990; Erickson, 1995; Flap, 1994; Lin, 1982; Lin, 1999; Portes, 1998; Putnam, 1995).

Previous research on the connection/relationship and information power and career success is rare. We did not find any prominent research in this topic except studies by Bahniuk and her colleagues. Bahniuk, Hill and Darus (1996), and Dobos, Bahniuk and Hill (1991) conducted a few series of studies on this topic. Hill, Bahniuk and Dobos (1994) developed a power-gaining communication model based on information power and connection power. They found that powergaining communication relationship enhances career success.

\section{Networking}

The present study adopts previously welldefined networking which states that "behaviors that are aimed at building, maintaining, and using informal relationships that possess the potential benefit to facilitate work-related activities of individuals by voluntarily granting access to resources and maximizing common advantages" (Forret \& Dougherty, 2004; Wolff \& Moser, 2008). Networking is analyzed at the behavioral level (Michael \& Yukl, 1993; Wanber, Kanfer \& Banas, 2000; Witt, 2004). Networking success depends on the ability to interact and to relate with others and that success comes not only with whom one knows, but also how one knows one another.

Mohd. Rasdi, Garavan and Ismail (2011), in their study on proactive behavior in 
Malaysia, found that networking behavior positively relates with objective and subjective career success of employees in the public sector in Malaysia. Networking affects career success through increased salary, promotion, and career satisfaction (Seibert, Kraimer \& Liden, 2001). This is not only among the employees of the private sector but also in the public sector. Networking behaviors can build and maintain informal contacts toward achieving career success (Forret \& Dougherty, 2004; Luthans, Rosenkrantz, \& Hennessey, 1985; Michael \& Yukl, 1993). Furthermore, networking correlates with performance (Sturges, Conway, Guest \& Liefhooghe, 2005; Thompson, 2005, cited in Wolff \& Moser, 2008). Based on the evidence from previous networking studies on career development process (Higgins \& Kram, 2001; Ismail \& Mohd Rasdi, 2007; Van Emmerik et al., 2006), we propose networking will produce communication power which in turn influences career success.

\section{Career Success}

Career success is conceptualized as "both real/objective and perceived/subjective achievements in individuals' work lives" (Judge, Cable, Boudreau, \& Bretz, 1995). For the present study, only objective career outcomes will be used. From the standpoint of objective career outcomes, career success of employees is mainly measured based on money and position (Feldman, 1989; Hall, 1976). Career success can also be looked at in terms of promotion, salary increment, individual performance, and one's success and contributions to the organization (Bowen, 1986; Kanter, 1977; Kram, 1983; Levinson et al., 1978; Morris, 1969; PhillipJones, 1982; Speizer, 1981).

Furthermore, objective career success is observable career accomplishments and they are tangible outcomes in nature. Therefore, objective career outcomes can be seen as increase in annual salary, scope of responsibility, promotion to a higher level, and receiving bonuses, incentives, and other fringe benefits.

\section{Information Power as a Mediator}

In this study, we propose communication power comprised of information power and relationship power. Information power comes from access to and control over information. According to Hershey, Blanchard and Natemeyer (1979), "information power is based on the possession of or access to information that is valuable to others (p. 419). Therefore, the person who possesses the needed information by other is influential and becomes powerful. Increased access to information enables employees to increase their knowledge and to help them deal with specific issues that they might have at work. Control of information flow usually relates to formal communication network. The more valuable the resource is to the company or superior and the greater is the level of mastery the person has on the information or materials, the more influential he/she will become.

Relationship power is based upon whom you know. Relationship power or connection power as termed by Hershey, Blanchard and Natemeyer (1979) refers to the power one gains from relationship with the power of others. Therefore, when one has the connections, he/she is bound to have the relationship power and thus becomes a popular emergent leader. The influence of power within the interaction of employees at workplace is significant. If one can reach, either directly or indirectly, the dominant coalition in the organization, one has a better prospect for influence and control over the whole organization.

Being liked and highly regarded among other teams and departments will increase one's chance of being promoted or influencing the outcome of a decision. Work connections are vehicle for resource and reward exchange. The result is that better-connected people do better (Burt, 2000).

\section{Personality and Self-Efficacy As Moderators}

A proactive personality is identified as "someone who is relatively unaffected by situational forces, and who actively initiates environmental change" (Bateman \& Crant, 
1993). Highly proactive persons tend to take action to ensure constructive outcomes (Cunningham \& De La Rosa, 2008; Parker \& Sprigg, 1999). Previous research has discussed proactive personality relationship with objective career success (Erdogan \& Bauer, 2005; Ng et al., 2005; Seibert et al., 1999). McCourt and Foon (2007), and Mohd Rasdi et al. (2011) argued that proactive behaviors have important direct and contingent effects on career outcomes. It is possible that proactive personality moderates the relationships between networking, communication power and career success.
Self-efficacy can moderate behavioral change (Bandura, 1977). Since self-efficacy refers to the belief in one's capability to perform a specific task, therefore, it can be summarized as one's capabilities to organize and execute courses of action required to attain desired goal, specifically, own performance at workplace (Bandura, 1986). Therefore, a self-efficacious employee is anxious to learn from others for self-development. With the support from networking and communication power, individuals with high self-efficacy are able to perform better and thus, succeed in their career endeavor.

H4

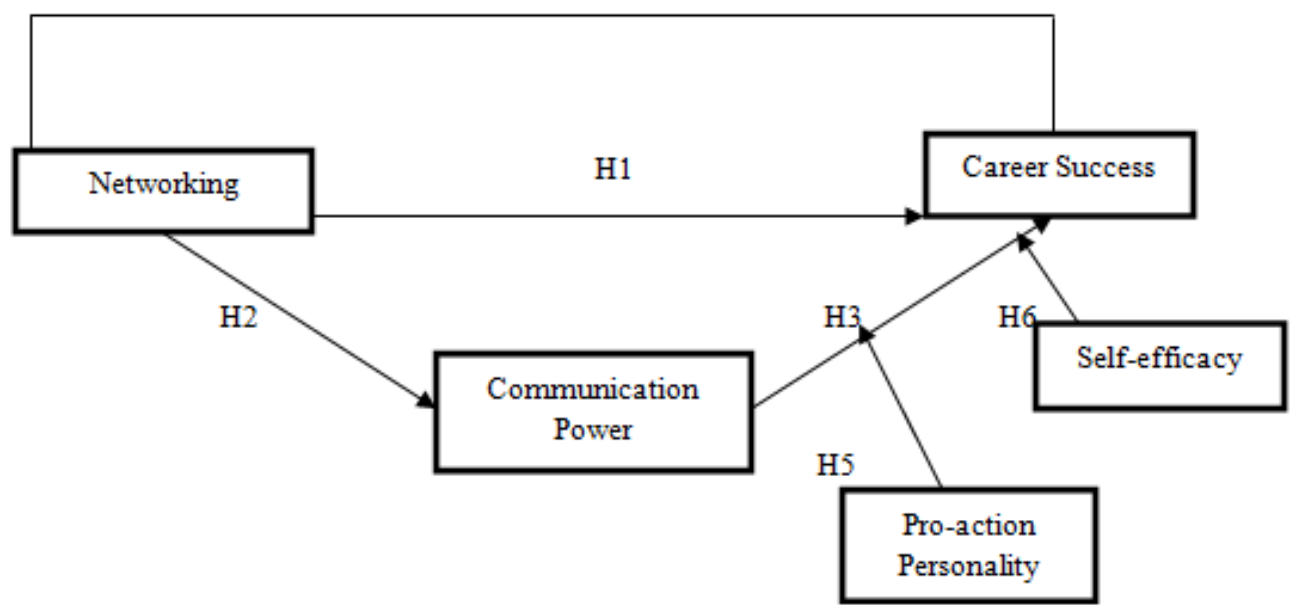

Figure 1: Conceptual Framework for the study

Based on the above literature (Figure 1), we develop the following hypotheses:

$\mathrm{H}_{1}$ : Networking positively correlates with career success.

$\mathrm{H}_{2}$ : Networking positively correlates with communication power.

$\mathrm{H}_{3}$ : Communication power positively correlates with career success.

$\mathrm{H}_{4}$ : Communication power mediates the relationship between networking and career success.

$\mathrm{H}_{5}$ : Proactive personality moderates the relationship between communication power and career success.
$\mathrm{H}_{6}$ : Self-efficacy moderates the relationship between communication power and career success.

\section{Methodology}

The study employs a quantitative research design. It uses a survey method and used questionnaire as the research instrument for data collection. A total of 308 respondents, comprising of the middle-level management level, representing various companies, such as, manufacturing, services, health, and education, were collected for the duration of two months. Trained enumerators were assigned to various locations in Kuala Lumpur and Selangor, Malaysia. 
Most of the measures are adapted from established scales. Career success items and networking items are adapted from Gevorkyan (2011), self-efficacy items are taken and adapted from Clark and Creswell (2010), and proactive personality items are taken and adapted from Owen (2009). Items for information power and relationship power are self-developed by the researchers. The constructs are found to be reliable with Cronbach's alpha (Table 1) for networking $(\alpha=.907)$, communication power $(\alpha=.929)$, personality $(\alpha=.896)$, and career success $(\alpha=.928)$. The dimensions of each construct were further confirmed by using Structural Equation Modelling (SEM) AMOS.

\begin{tabular}{|c|c|c|c|c|c|}
\hline Variable & Dimension & Mean & $\begin{array}{l}\text { Standard } \\
\text { deviation }\end{array}$ & No. of Items & $\begin{array}{c}\text { Cronbach's } \\
\text { alpha } \\
(n=308)\end{array}$ \\
\hline \multirow[t]{3}{*}{ Networking } & $\begin{array}{l}\text { Intermal } \\
\text { contact }\end{array}$ & 3.658 & 0.548 & 10 & .852 \\
\hline & $\begin{array}{l}\text { External } \\
\text { contact }\end{array}$ & 3.330 & 0.669 & 10 & 900 \\
\hline & $\begin{array}{l}\text { Overall } \\
\text { Organizational } \\
\text { networking }\end{array}$ & 3.494 & 0.529 & 20 & 907 \\
\hline \multirow[t]{3}{*}{$\begin{array}{l}\text { Communication } \\
\text { Powver }\end{array}$} & $\begin{array}{l}\text { Information } \\
\text { power }\end{array}$ & 3.578 & 0.563 & 10 & .872 \\
\hline & $\begin{array}{l}\text { Relationship } \\
\text { powver }\end{array}$ & 3.522 & 0.654 & 10 & 909 \\
\hline & $\begin{array}{l}\text { Overall } \\
\text { communication } \\
\text { powver }\end{array}$ & 3.550 & 0.557 & 20 & 929 \\
\hline \multirow[t]{3}{*}{ Personality } & Proactive & 3.750 & 0.562 & 10 & 902 \\
\hline & $\begin{array}{l}\text { General self- } \\
\text { efficacy }\end{array}$ & 3.654 & 0.603 & 10 & 920 \\
\hline & $\begin{array}{l}\text { Overall } \\
\text { personality }\end{array}$ & 3.706 & 0.526 & 20 & 896 \\
\hline Career Success & & 3.487 & 0.696 & 9 & 928 \\
\hline
\end{tabular}

\section{Findings of the Study}

The majority of the respondents $(n=308)$ of the study are Malays (81.8\%), comprising of 162 females and 146 males, mainly belonged to the 26-35 age group (43.2\%), and with Bachelor's degree (46.1\%). In terms of jobrelated characteristics, the respondents mainly worked in the public sector inclusive of with the Government of Malaysia (51.9\%) worked in the private sector (48.1\%) and with 158 of them with 1-5 years of working experience, almost all work on a full-time basis, as executive officers $(36.0 \%)$ and on a full-time basis.

\section{Measurement Model}

Using Maximum Likelihood (ML) Estimation, Confirmatory Factor Analysis (CFA) was conducted separately for all the constructs in this study: internal contact (INT), external contact (EX), information power (INF), relational power (REL), and career success (CS) to test their reliability and validity. Table 2 provides valid items for the measurement model. Several fit statistics were employed to test the measurement model. These include normative Chi square $\left(X^{2} / d f\right)$, Comparative Fit Index (CFI), TuckerLewis Index (TLI), and Root Mean Square Error Approximation (RMSEA). A good fitting model can be achieved when the normative Chi square is less than 3, CFI and TLI greater than .90 and RMSEA is less than .05 (best) or .080 (acceptable). Table 3 details the recommended and actual values for the fitting model (Figure 2). 
Table 2: Valid items for measurement model

\begin{tabular}{|c|c|c|c|c|c|c|}
\hline Construct & Label & Items & Loadings & $\mathbf{M}$ & SD & Alpha \\
\hline \multirow{5}{*}{$\begin{array}{l}\text { Intemal } \\
\text { contact }\end{array}$} & INT4 & $\begin{array}{l}\text { If I want to meet a person who could be of } \\
\text { professional importance to me I take the initiative } \\
\text { and introduce myself. }\end{array}$ & 58 & 3.731 & 0.784 & \multirow{5}{*}{.852} \\
\hline & INT5 & $\begin{array}{l}\text { When a colleague from another department asks me } \\
\text { for help with a professional matter, I help him/her, } \\
\text { even if it is not part of my job. }\end{array}$ & .66 & 3.718 & 0.804 & \\
\hline & INT6 & $\begin{array}{l}\text { If a colleague has assisted me with a difficult } \\
\text { problem, I inform him of the outcome once the } \\
\text { problem has been resolved. }\end{array}$ & .71 & 3.727 & 0.785 & \\
\hline & INT? & $\begin{array}{l}\text { When instructions or work documents are not stated } \\
\text { clearly, I ask colleagues for clarification. }\end{array}$ & .69 & 3.890 & 0.783 & \\
\hline & INT8 & $\begin{array}{l}\text { I discuss upcoming organizational changes with } \\
\text { colleagues from other departments. }\end{array}$ & 59 & 3.526 & 0.936 & \\
\hline \multirow{6}{*}{$\begin{array}{l}\text { Exterual } \\
\text { contact }\end{array}$} & EX1 & $\begin{array}{l}\text { I develop informal contacts with professionals } \\
\text { outside the organization, in order to have personal } \\
\text { links beyond the company. }\end{array}$ & .63 & 3.464 & 0.946 & \multirow{6}{*}{900} \\
\hline & EX4 & $\begin{array}{l}\text { I accept invitations to official functions or festivitis } \\
\text { out of professional interest. }\end{array}$ & .72 & 3.409 & 0.847 & \\
\hline & EX5 & $\begin{array}{l}\text { I meet with acquaintances from other organizations } \\
\text { outside of regular working hours. }\end{array}$ & .66 & 3.062 & 0.913 & \\
\hline & EX8 & $\begin{array}{l}\text { I exchange professional tips and hints with } \\
\text { acquaintances from other organizations. }\end{array}$ & .74 & 3.325 & 0.838 & \\
\hline & EX9 & $\begin{array}{l}\text { When I can't solve a problem at work I call } \\
\text { acquaintances from other organizations and ask for } \\
\text { advice. }\end{array}$ & .73 & 3296 & 0.920 & \\
\hline & EX10 & $\begin{array}{l}\text { I use my contacts outside my company, to ask for } \\
\text { business advice. }\end{array}$ & 80 & 3266 & 0.989 & \\
\hline \multirow{6}{*}{$\begin{array}{l}\text { Relationship } \\
\text { power }\end{array}$} & REL2 & $\begin{array}{l}\text { I communicate well with the high ranking people in } \\
\text { the organization. }\end{array}$ & 59 & 3.578 & 0.856 & \multirow{6}{*}{909} \\
\hline & REL5 & I have many subordinates to help me. & .68 & 3.526 & 0.875 & \\
\hline & REL6 & $\begin{array}{l}\text { I have the influence on people through } \\
\text { communication. }\end{array}$ & .74 & 3.578 & 0.797 & \\
\hline & REL ? & I hold important position in my organization. & 73 & 3.435 & 0916 & \\
\hline & REL9 & I stand high in the organizational chart position. & 82 & 3364 & 0.930 & \\
\hline & REL10 & I am good at interpersonal communication. & .68 & 3.679 & 0.837 & \\
\hline \multirow{5}{*}{$\begin{array}{l}\text { Information } \\
\text { power }\end{array}$} & INF1 & I have the information that others do not have. & 61 & 3.364 & 0.872 & \multirow{5}{*}{.872} \\
\hline & INF2 & $\begin{array}{l}\text { I have the information that I want to share with } \\
\text { them. }\end{array}$ & .49 & 3.623 & 0.808 & \\
\hline & INF5 & I have access to important information nesded. & .66 & 3.669 & 0.704 & \\
\hline & INF6 & I can withhold scarce information. & .65 & 3516 & 0.793 & \\
\hline & INF? & I have the control of information in organization. & 71 & 3399 & 0.962 & \\
\hline \multirow{7}{*}{$\begin{array}{l}\text { Career } \\
\text { success }\end{array}$} & $\operatorname{cS} 1$ & $\begin{array}{l}\text { I am satisfied with the success I have achieved in my } \\
\text { career. }\end{array}$ & .86 & 3386 & 0.919 & \multirow{7}{*}{928} \\
\hline & $\operatorname{cs} 2$ & $\begin{array}{l}\text { I am satisfied with the progress I have made toward } \\
\text { meeting my goals for income. }\end{array}$ & .86 & 3.403 & 0.862 & \\
\hline & $\operatorname{cs} 3$ & $\begin{array}{l}\text { I am satisfied with the progress I have made toward } \\
\text { meeting my goals for the development of new skills. }\end{array}$ & 84 & 3.549 & 0.791 & \\
\hline & $\operatorname{cS} 4$ & I am satisfied with my opportunities for promotion. & 75 & 3.464 & 0.904 & \\
\hline & $\operatorname{cs5}$ & $\begin{array}{l}\text { I am satisfied with the pro gress I have made toward } \\
\text { meeting my overall career goals. }\end{array}$ & .82 & 3.523 & 0.840 & \\
\hline & $\operatorname{cs} 6$ & $\begin{array}{l}\text { I an satisfied with the success I have achieved in my } \\
\text { career. }\end{array}$ & .74 & 3386 & 0.919 & \\
\hline & $\operatorname{cs} 8$ & $\begin{array}{l}\text { I have reached my career goals within the time } \\
\text { frame I have set for myself. }\end{array}$ & .64 & 3.422 & 0.908 & \\
\hline
\end{tabular}


Table 3: recommended fit statistics for measurement model and structural model

\begin{tabular}{|c|c|c|c|}
\hline Fit Indices & $\begin{array}{c}\text { Recommended } \\
\text { Values }\end{array}$ & Measurement Model & Structural Model \\
\hline $\mathrm{X}^{2}$ & & 1343.293 & 715.781 \\
\hline df & & 756 & 368 \\
\hline $\mathrm{X}^{2} / \mathrm{df}=$ & $<3$ & 1.753 & 1.945 \\
\hline CFI & $\geq 90$ & .935 & .917 \\
\hline TLI & $\geq 90$ & .928 & .909 \\
\hline RMSEA & $<.08, .05$ & .049 & .055 \\
\hline
\end{tabular}

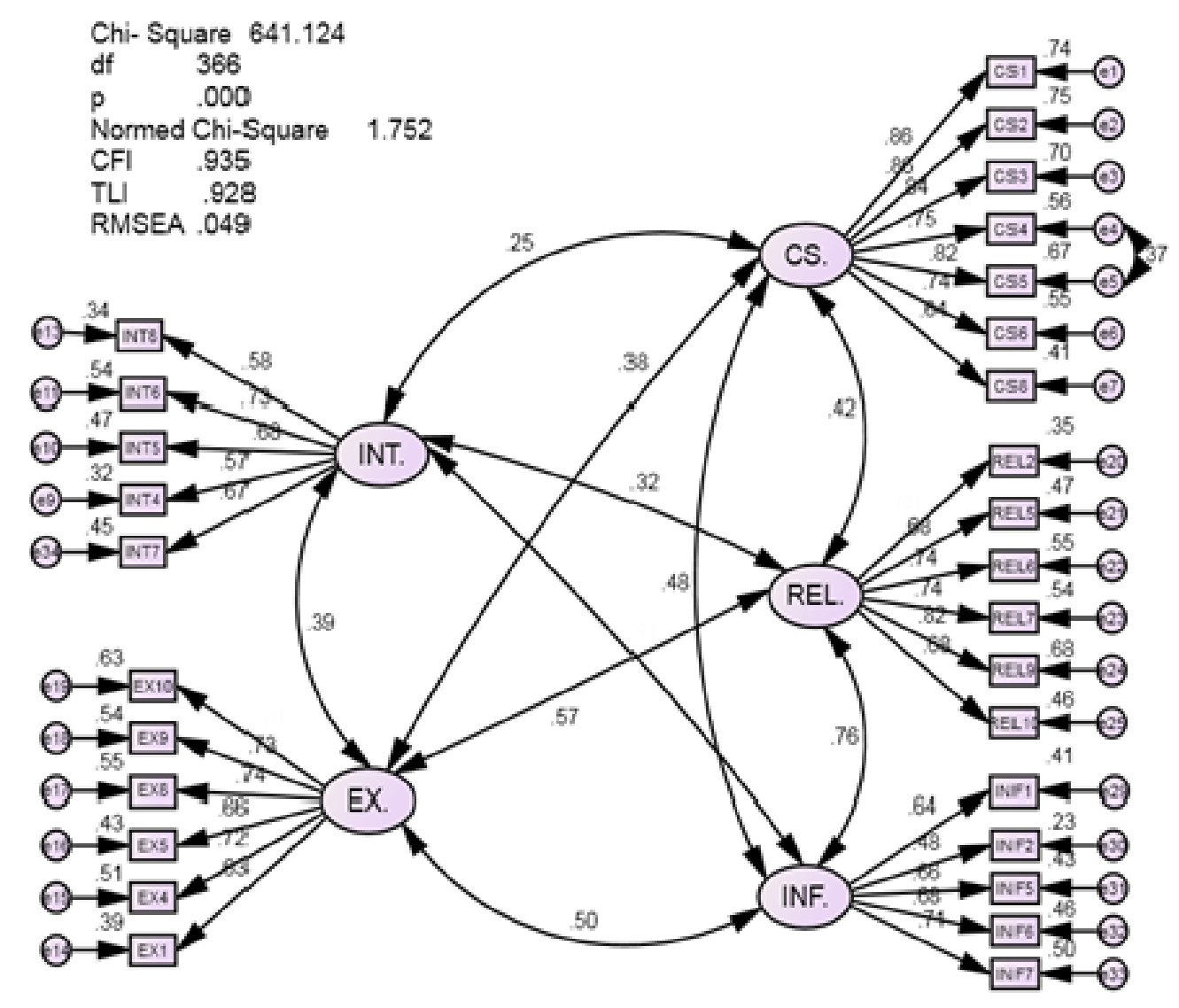

Fgure 2: Measurement Model 
The initial CFAs failed to fit well to the empirical data. Therefore, they were revised accordingly. The revised CFAs had met the threshold of goodness of fit indices. The fit statistics suggested that INT $\left(X^{2} / d f=3.00\right.$, $C F I=.961, T L I=.935, R M S E A=.081) ; \operatorname{EX}\left(X^{2} / d f=\right.$ 2.567, $C F I=.980, T L I=.967, R M S E A=.071)$; INF $\left(X^{2} / d f=2.492, \quad C F I=.973, \quad T L I=.954\right.$, $R M S E A=.070) ; \operatorname{REL}\left(X^{2} / d f=1.978, C F I=.988\right.$, $T L I=.980, R M S E A=.056)$; and CS $\left(X^{2} / d f=1.656\right.$, $C F I=.984, \quad T L I=.990, \quad R M S E A=.046)$ were consistent with the empirical data. Several items were dropped due to estimation violations as suggested by modification indices. Consequently, these constructs were combined in the measurement model to test the convergent validity and discriminant validity (Table 4). The measurement model (Model 2) suggests adequate fit to the data $\left(X^{2 / d} f=1.752, \quad C F I=.935, \quad T L I=.928\right.$, RMSEA =.049). The factor loadings and covariance were statistically significant at .05. The highest correlation was between relational power and information power ( $\mathrm{r}=.76, p=.000)$, followed by external networking and relational power $(\mathrm{r}=.57$, $p=.000$ ).

Table 4: construct reliability and validity

\begin{tabular}{|l|r|r|r|r|r|r|r|r|}
\hline & \multicolumn{1}{|l|}{ CR } & \multicolumn{1}{|c|}{ AVE } & \multicolumn{1}{|c|}{ ASV } & \multicolumn{1}{l|}{ CS } & \multicolumn{1}{l|}{ INT } & \multicolumn{1}{l|}{ INF } & \multicolumn{1}{l|}{ REL } & EX \\
\hline CS & 0.920 & 0.625 & 0.159 & $\mathbf{0 . 7 9 1}$ & & & & \\
\hline INT & 0.788 & 0.404 & 0.156 & 0.289 & $\mathbf{0 . 6 1 9}$ & & & \\
\hline INF & 0.771 & 0.406 & 0.320 & 0.483 & 0.463 & $\mathbf{0 . 6 3 8}$ & & \\
\hline REL & 0.860 & 0.509 & 0.304 & 0.421 & 0.369 & 0.759 & $\mathbf{0 . 7 1 3}$ & \\
\hline EX & 0.860 & 0.508 & 0.228 & 0.376 & 0.437 & 0.505 & 0.571 & $\mathbf{0 . 7 1 3}$ \\
\hline
\end{tabular}

Note: Bold diagonal numbers denotes the square root of AVE which should be more than the intercerrelations for adequate discriminant validity.

$\mathrm{CR}=$ composite reliability, $\mathrm{AVE}=$ average variance extracted, $\mathrm{ASV}=$ average shared variance, $\mathrm{CS}=$ career success, INT= intemal networking, INF= information power, REL = relational power, and $\mathrm{EX}=$ external networking.

\section{Structural Model}

Using the same criteria as discussed in the measurement model, the fit statistics were satisfactorily good, with $\mathrm{X}^{2} / d f=1.945$, CFI=.917, TLI=.909, RMSEA=.055 (Figure 3). This study hypothesized that the two dimensions of networking (internal and external) would have significant impact on the two dimensions of communication power (information and relationship), which in turn, significantly influence the career success among the respondents.
Therefore, the hypothesized model suggested that internal contact had statistically significant impact on information power $(\beta=.31, p=.000)$ and relational power $(\beta=.17$, $p=.013$ ), whereas external networking exerted significant influence on information power $(\beta=.42, p=.000)$, as well as relational power $(\beta=.53, p=.000)$. In addition, the two dimensions of communication power significantly influenced the endogenous variable (career success), with $\beta=.37, p=.000$ for information power and $\beta=.20, p=.003$ for relational power (Table

Table 5: results of revised hypothesized model

\begin{tabular}{|l|l|l|r|r|c|}
\hline \multicolumn{2}{|c|}{ Hypotheses } & \multicolumn{1}{c|}{ Path coefficients } & $\begin{array}{c}\text { t-value } \\
(>1.96)\end{array}$ & Sign & Remarks \\
\hline INT & $\rightarrow$ INF & 0.31 & 3.802 & .000 & Significant \\
\hline EX & $\rightarrow$ INF & 0.42 & 5.235 & .000 & Significant \\
\hline INT & $\rightarrow$ REL & 0.17 & 2.472 & .013 & Significant \\
\hline EX & $\rightarrow$ REL & 0.53 & 6.116 & .000 & Significant \\
\hline REL & $\rightarrow$ & & 3.001 & .003 & Significant \\
\hline INF & $\rightarrow$ & 0.20 & 5.034 & .000 & Significant \\
\hline
\end{tabular}




\section{Mediating Effect of Communication Power Dimensions}

The mediating test was conducted based on Baron and Kenny's (1986) guidelines and it was confirmed with the Sobel test (1982). Baron and Kenny suggest that all variables concerned must be significantly related to one another. The mediator should significantly be affecting the outcome variable. Internal contact and external contact are exogenous variables in this study, whereas information power and relational power are the mediating variables. Career success is the only endogenous variable.

Looking at the path coefficients of the revised model, it was found that the impact of the exogenous variables (internal contact and external contact) on information power and relational power were statistically significant. However, they had no direct effects on the endogenous variable. In addition, information power and relational power (the mediators) had significant effects on the dependent variable. Therefore, the recommended criterion for mediation testing was achieved.

Sobel test the significance of mediating effects. The Sobel test suggested significant t- tests for external contact ( $t=1.876, p=.030$ ) indicating that information power fully mediates the relationship of these constructs with career success, whereas relational power $(t=1.585, p=.056)$ did not mediate internal contact on career success. However, information power significantly mediates on internal contact toward career success $(t=2.662, p=.003)$, as well as on external contact toward career success $(t=3.029$, $p=.001$ ).

\section{Moderating Effect of Personality}

Structural invariance was conducted in order to see whether the model works in a similar way for both low $(N=153)$ and high $(N=155)$ proactive personality groups. Table 6 summarizes the results of invariance analysis (moderating effect). As for the proactive personality, the Chi-square for the unrestricted model was $1287.281(d f=f 742)$, whereas the Chi-square for the fully constrained model was $1329(d f=769)$. The Chi-square difference (41.947) was significant since it is more than the critical value $(\mathrm{CV}=40.11)$. It means that both low and high personality groups are different at the structural level. Overall, it can be concluded that proactive personality moderates the revised hypothesized model.

Table 6: results of moderating effects of proactive personality and general self-efficacy

\begin{tabular}{|c|c|c|c|c|c|c|}
\hline & $\mathrm{X}^{2}$ & $\mathrm{df}$ & $\begin{array}{c}\text { df } \\
\text { difference }\end{array}$ & Criticalvalue & $\begin{array}{c}\mathrm{X}^{2} \\
\text { change }\end{array}$ & Remarks \\
\hline \multicolumn{7}{|l|}{ Personality } \\
\hline \multicolumn{7}{|l|}{$\begin{array}{l}\text { Proactive } \\
\text { pers onality }\end{array}$} \\
\hline $\begin{array}{l}\text { Unrestricted } \\
\text { model }\end{array}$ & 1287.281 & 742 & 27 & 40.11 & $41.947^{8}$ & $\begin{array}{l}\text { Pers onality } \\
\text { moderates the }\end{array}$ \\
\hline $\begin{array}{l}\text { Fully constrained } \\
\text { model }\end{array}$ & 1329.228 & 769 & & & & model. \\
\hline \multicolumn{7}{|l|}{$\begin{array}{l}\text { General self- } \\
\text { efficacy }\end{array}$} \\
\hline $\begin{array}{l}\text { Unrestricted } \\
\text { model }\end{array}$ & 1220.039 & 736 & \multirow{2}{*}{30} & \multirow{2}{*}{43.77} & \multirow{2}{*}{$52.569^{\circ}$} & \multirow{2}{*}{$\begin{array}{l}\text { The model has } \\
\text { variant across } \\
\text { low and high } \\
\text { self-efficacy. }\end{array}$} \\
\hline $\begin{array}{l}\text { Fully constrained } \\
\text { model }\end{array}$ & 1272.608 & 766 & & & & \\
\hline
\end{tabular}

$\star=$ Statistically significant at .05 level

General self-efficacy was also tested for its moderating effects on the hypothesized model (Figure 3). The Chi-square value of the unrestricted model $(1220.04, d f=736)$ was less than the Chi square value of the fully constrained model (1272.61, $d f=766)$. The Chi-square difference (52.57) was significant at 0.05 and greater than the critical value 
(43.77). Therefore, general self-efficacy significantly moderates the model

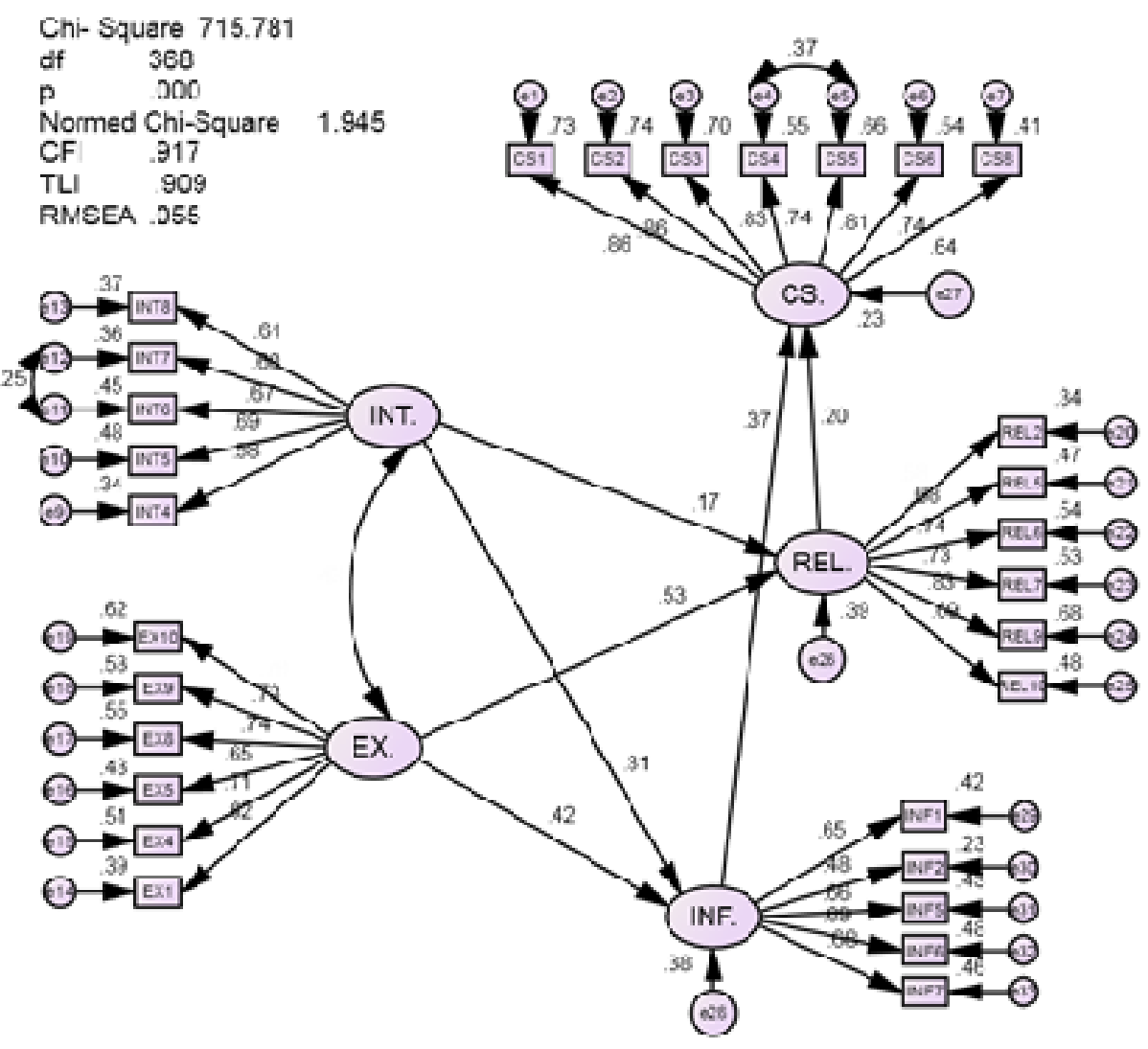

Figure 3: Results of the hypothesized model

This study tests the mediating effect of communication power dimension on networking dimensions toward career success. This study validated a model hypothesizing that internal contact and external contact are influential factors of information power and relational power, which in turn, influence the career success.

Prior testing the hypothesized model, a confirmatory factor analysis using MLE, to provide evidence of the construct validity and reliability, was conducted. The structural model, then, was tested using the same criteria and adequately fitted to the empirical data. There were significant impact of internal and external contact on both information power and relational power. The information power significantly mediated the relationship of the two dimensions of networking with career success, whereas relational power did not mediate that relationship. On the other hand, personality dimensions, namely, proactive personality and general self-efficacy significantly moderated the hypothesized model. Therefore, all the hypotheses are supported.

\section{Discussion and Conclusion}

This study examines how networking contributes to career success. Specifically, it tests communication networks, organizational contacts, and communication power on career success. The study found that both social and professional networks enhance career success.

The theory of social capital that postulates active interaction among people in a circle or 
group is used to gain access to information which is perceived as valuable is supported by the study. The significant relationship between networking and information power supports the previous findings (Forret \& Dougherty, 2004; Wolff \& Moser, 2006) that suggest organizational behavior that is aimed to build, maintain and use informal relationship is to gain benefits and common advantages. The benefits gained from the networking could enhance an individual's reputation in acquiring valuable rewards and resources from the organization regardless of the actual job performance (Ferris \& Judge, 1991; Luthans et al., 1988).

The study implies that employees in Malaysia use their communication networks beyond just getting connected with their friends. The employees take the advantage both the internal and external linkages. In fact, coworker sites, as social media platform, should be used for their survival to enhance career advancement at the workplace. Therefore, senior managers need to develop a clear communication strategy, using both vertical and horizontal linkages through SNS for career development purposes.

Boundary spanners, with internal and external linkages, are at a strategic position of their organizations. They should harness the information power besides depending on just relational power. Their positions are strategic for career success where they can easily forge joint venture projects with other organizations for the benefit of their own organization. Practically speaking, networking is one of the means for having access and control over useful information at work. Therefore, it is good to provide employees with networking opportunities which are beneficial for their career success. Given the variety of methods in networking that ranged from online, offline and face-toface, it is good to diversify the networking means. Indeed, SNS could be used to enhance networking. The Social Capital Theory holds true for this study, with all the hypotheses being supported.

There are a few limitations of this study that need to be mentioned. The demographic characteristics of the respondents indicated that the majority of them are Malays.
Therefore, the findings of the study have to be interpreted with caution. This is because due to tradition among the Malaysians, especially the Malays, are inclined to rate themselves lower. They are brought up to be humble, not to project themselves. They usually hesitate to rate the highest scale, especially for their achievement. The insignificant moderating effect of SNS infers other possible moderating variables. We could speculate the role of culture and/or ethnicity for networking and information power studies in the future. Culture and/or ethnicity might have a bearing in the preferred methods of networking (e.g., faceto-face and online) that could influence the effectiveness of networking on information power. Therefore, in future studies, it is worth examining the role of culture and/or ethnicity as the moderator.

Obviously, more research is needed on networking for career development and success as communication networks, organizational contacts and communication are hastened by the use of SNS, when they are diligently used. The present study triggers more studies in this subject. SNS may be a major contributor in knowledge sharing but not for obtaining power over the information. It is plausible to see how knowledge sharing is different from information power. The former aims to share and disseminate information with others; however, the latter intends to control the dissemination of information. Future studies should look into knowledge sharing and information power.

\section{References}

1. Aquino, K., Griffeth, R W., Allen, D G. and Hom, P W. (1997), 'Integrating justice constructs into the turnover process: A test of a referent cognitions model,' Academy of Management Journal, 40, 1208-1227.

2. Bahniuk, M., Hill, S. and Darus, H. (1996), 'The relationship of power-gaining communication strategies to career success,' Western Journal of Communication, 60 (4), 358-378.

3. Bandura, A. (1977) Social Learning Theory, Prentice Hall, Englewood Cliffs, New Jersey. 
4. Bandura, A. (1986) Social Foundations of Thought and Action: A Social Cognitive Theory, Prentice Hall, Englewood Cliffs, New Jersey.

5. Baron, R M. and Kenny, D A. (1986), 'The moderator-mediator variable distinction in social psychological research: Conceptual, strategic, and statistical considerations,' Journal of Personality and Social Psychology, 51, 1173-1182.

6. Bateman, T S. and Crant, J M. (1993), 'The proactive component of organizational behavior: A measure and correlates,' Journal of Organizational Behavior, 14, 103-118.

7. Bourdieu, P. (1986), The forms of capital, Handbook of Theory and Research for the Sociology of Education, Richardson, J G. (ed), Greenwood Press, Westport, Connecticut.

8. Bowen, D. (1986) 'The role of identification in mentoring female mentees,' Group and Organization Studies, 11 (2), 6174.

9. Burt, R S. (1992) Structural Holes: The Social Structure of Competition, Harvard University Press, Cambridge, Massachusetts.

10. Burt, R S. (1997) The contingent value of social capital, Administrative Science Quarterly, 42 (2), 339-365.

11. Burt, R S. (2000) 'The network structure of social capital,' Research in Organizational Behavior, 22, 345-423.

12. Castells, M. (2007) 'Communication, power and counter-power in the network society,' International Journal of Communication, 1, 238-206.

13. Clark, V L. and Creswell, J W. (2010) Understanding Research: A Consumer's Guide, Prentice Hall- Merrill, Upper Saddle River, New Jersey.

14. Coleman, J S. (1990) Foundations of Social Theory, Harvard University Press, Cambridge, Massachusetts.

15. Cunningham, C J L. and De Le Rosa, G. (2008), 'Proactive personality as a complex moderator in the stress process,' Journal of
Occupational Health Psychology, 13 (3), 271282.

16. Dobos, J., Bahniuk, M. and Hill, S. (1991), 'Power-gaining communication strategies and career success,' Southern Communication Journal, 57 (1), 35-48.

17. Erdogan, B. and Bauer, T N. (2005), 'Enhancing career benefits of proactive personality: The role of fit with jobs and organizations,' Personnel Psychology, 58, 859891.

18. Erickson, B H. (1995), 'Networks, success, and class structure: A total view,' Sunbelt Social Networks Conference, 11-14 May 1995, Charleston.

19. Feldman, D C. (1989) 'Careers in organizations: Recent trends and future directions,' Journal of Management, 15, 135156.

20. Ferris, G R. and Judge, T A. (1991), 'Personnel/human resources management: A political influence perspective,' Journal of Management, 17, 447-488.

21. Flap, H D. (1994) 'No man is an island: The research program of a social capital theory', World Congress of Sociology, 20 July 1994, Bielefeld, Germany.

22. Forret, M F. and Dougherty, T W. (2004), 'Networking behavior and career outcomes: Differences for men and women?', Journal of Organizational Behavior, 25, 419-437.

23. Gevorkyan, A V. and Gevorkyan, Ar. (2011), Fundamental Uncertainty, Reserves Funds, and Fiscal Policy Rules in Emerging Financial Markets, Unpublished draft, available upon request.

24. Hall, D T. (1976) Careers in Organization, Goodyear, Santa Monica, California.

25. Hershey, P., Blanchard, K H., and Natemeyer, W E. (1979), 'Situational leadership, perception, and the impact of power,' Group and Organizational Studies, 4, 418-428.

26. Higgins, M. and Kram, K. (2001), 'Reconceptualizing mentoring at work: A developmental 
network perspective,' Academy of Management Review, 26 (2), 264-288.

27. Hill, S E K., Bahniuk, M H., Dobos, J. and Rouner, D. (1989), 'Mentoring and other communication support in the academic setting,' Group and Organization Studies, 14, 355-368.

28. Ismail, M. and Mohd Rasdi, R. (2007), 'Impact of networking on career development: Experience of high-flying women academics,' Human Resource Development International, 10 (2), 157-72.

29. Judge, T A., Cable, D M., Boudreau, J W. and Bretz, R D. Jr. (1995), 'An empirical investigation of the predictors of executive career success,' Personnel Psychology, 48, 485-519.

30. Kanter, R M. (1977) Men and Women of the Corporation, Basic Books, New York, New York.

31. Koberg, C S., Boss, R W. and Goodman, E. (1998), 'Factors and outcomes associated with mentoring among health care professionals,' Journal of Vocational Behavior, 53 (1), 58-72.

32. Kram, K E. (1983) 'Phases of the mentor relationship,' Academy of Management Journal, 26 (4), 608-625.

33. Langford, P H. (2000) Importance of relationship management for the career success of Australian managers,' Australian Journal of Psychology, 2, 163-168.

34. Levinson, D J., Darrow, C L., Klein, E., Levinson, M. and Mekee, B. (1978) The Seasons of a Man's Life, Alfred A. Knopf, New York, New York.

35. Lin, N. (1999) 'Building a network theory of social capital,' Connections, 22 (1), 28-51.

36. Lin, N., Ensel, W M. and Vaughn, J C. (1981), 'Social resources and occupational status attainment,' Social Forces, 59 (5), 1163-1181.

37. Lin, N., Ensel, W M. and Vaughn, J C. (1982), 'Social resources and strength of ties,'
American Sociological Review, 46 (4), 393405.

38. Luthans, F., Rosenkrantz, S A. and Hennessey, H W. (1985), 'What do successful managers really do? An observation study of managerial activities,' Journal of Applied Behavioral Science, 21, 255-270.

39. Luthans, F., Hodgetts, R M. and Rosenkrantz, S A. (1988) Real Managers, Ballinger, Cambridge, Massachusetts.

40. Mccourt, W. and Foon, L M. (2007), 'Malaysia as model: Policy transferability in an Asian country,' Public Management Review, 9 (2), 211-229.

41. Michael, J. and Yukl, G. (1993), 'Managerial level and subunit function as determinants of networking behavior in organizations,' Group \& Organization Management, 18 (3), 28-351.

42. Mohd. Rasdi, R., Garavan, T. and Ismail, M. (2011), 'Understanding proactive behaviours and career success: Evidence from an emerging economy,' Organizations and Markets in Emerging Economies, 2 (4), 53-71.

43. Morris, W. (1969) The American Heritage Dictionary. Houghton Mifflin, New York, New York.

44.Ng, T W H., Eby, L T., Sorensen, K L. and Feldman, D C. (2005), 'Predictors of objective and subjective career success: A metaanalysis,' Personnel Psychology, 58, 367-408.

45.Nierenberg, A R. (2002) Nonstop Networking, Capital Books, Hendon, Virginia.

46.Orpen, C. (1996) 'Dependency as a moderator of the effects of networking behavior on managerial career success,' The Journal of Psychology, 130 (3), 245-248.

47.Owen, C. (2009) Toward developmental work in complex and fallible systems, Risky Work Environments: Reappraising Human Work within Fallible Systems, Owen, C., Beguin, P. and Wackers, G. (eds), Aldershot, Ashgate.

48.Parker, S K. and Sprigg, C A. (1999), 'Minimizing strain and maximizing learning: 
The role of job demands, job control, and proactive personality,' Journal of Applied Psychology, 84 (6), 925-939.

49.Phillip-Jones, L. (1982) Mentors and Mentees, Arbor House, New York, New York.

50.Portes, A. (1998) 'Social capital: Its origins and applications in modern sociology,' Annual Review of Sociology, 22, 1-24.

51.Putnam, R D. (1995) 'Bowling alone, revisited,' The Responsive Community, Spring, 18-33.

52.Seibert, S E., Crant, J M. and Kraimer, M L. (1999), 'Proactive personality and career success,' Journal of Applied Psychology, 84, 416-427.

53.Seibert, S E., Kraimer, M L. and Liden, R C. (2001), 'A social capital theory of career success,' Academy of Management Journal, 44 (2), 219-237.

54.Sobel, M E. (1982) Asymptotic intervals for indirect effects in structural equations models, Sociological Methodology, Leinhart, S. (ed.), Jossey-Bass, San Francisco, California.

55.Speizer, J. (1981) 'Role models, mentors and sponsors: The elusive concepts,' Signs, 6 (4), 692-712.
56.Thompson, J A. (2005) 'Proactive personality and job performance: A social capital perspective,' Journal of Applied Psychology, 90, 1011-1017.

57.Torres, N L. (2005) 'It's who you know,' Entrepreneur, 33, 128-132.

58.Van Emmerik, I J H., Euwema, M C., Geschiere, M. and Schouten, M. (2006), 'Networking your way through the organization: The relationship between participating in formal networks and career satisfaction,' Women in Management Review, 21 (1), 54-66.

59.Wanberg, C R., Kanfer, R. and Banas, G T. (2000), 'Predictors and outcomes of networking intensity among unemployed job seekers,' Journal of Applied Psychology, 85, 491-503.

60.Welch, M S. (1980) Networking, Harcourt Brace Jovanovich, New York, New York.

61.Witt, P. (2004) 'Entrepreneurs' networks and the success of start-ups,' Entrepreneurship \& Regional Development, 16, 391-412.

62.Wolff, H. and Moser, K. (2008) Effects of Networking on Career Success: A Longitudinal Study, LASER Discussion Papers, Paper No. 24. 